\title{
KIAT MEMBIMBING SISWA UNTUK MENINGKATKAN KEPERCAYAAN DIRI DALAM BERGAUL
}

\section{Oleh Zainuddin $^{1}$}

\begin{abstract}
Abstrak : Percaya diri adalah pandangan seseorang, gambaran pemikiran dan perasaan yakin, kesanggupan dan keberanian seseorang terhadap segala aspek kemampuan yang dimilikinya. Sumber dari percaya diri adalah wawasan dan pengetahuan seseorang. Luasnya wawasan dapat memudahkan untuk menyesuaikan diri terhadap dalam segala kondisi. Untuk itu, giat dalam mengeksplorasi kemampuan sangat penting. Mengeksplorasi segenap kemampuan dengan giat belajar dan terus berlatih. Berani mencoba hal-hal baru dan tantangan-tantangan baru dalam tugas yang dipercayakan. Komunikasi dan interaksi terhadap orang lain juga sangat penting dalam meningkatkan ilmu pengetahuan guna meningkatkan kepercayaan diri. Aktif berinteraksi seperti banyak berbicara dan berdiskusi mengenai pelajaran, masalah-masalah, atau kejadian-kejadian.
\end{abstract}

Kata kunci : Kepercayaan diri, pergaulan

\section{Pendahuluan}

Dalam kehidupan seseorang, masa remaja merupakan fase yang sangat potensial bagi pertumbuhan dan perkembangan baik aspek fisik maupun aspek psikis, baik secara kuantitatif maupun kualitatif. Remaja menganggap dirinya sudah bukan anak-anak lagi, tetapi orang-orang disekelilingnya masih menganggap mereka belum dewasa. Seringkali remaja ingin bertindak sebagaimana orang dewasa, tetapi perilaku mereka seringkali masih infulsif dan belum menunjukkan kedewasaan. Karena dorongan yang kuat ingin menemukan dan menunjukkan jati dirinya, remaja seringkali berusaha ingin melepaskan diri dari orang tuanya dan mengarahkan perhatiannya kepada lingkungan diluar keluarganya sehingga cenderung lebih senang bergabung dengan teman sebayanya.

Melihat masa remaja sangat potensial dan potensi itu dapat saja berkembang ke arah positif maupun negatif, maka sudah barang tentu intervensi edukasi dalam bentuk pendidikan, bimbingan, maupun

${ }^{1}$ Zainuddin adalah dosen Jurusan Pendidikan Dasar FKIP Untan 
pendamping sangat diperlukan untuk mengarahkan perkembangan potensi remaja tersebut agar berkembang ke arah yang positif dan produktif. Intervensi edukasi ini harus sejalan dan seimbang, baik dari pihak keluarga/ orang tua, sekolah maupun masyarakat. Kerjasama yang baik antara ketiga komponen ini harus dijalin sebaik-baiknya agar secara simultan dapat mencegah remaja berkembang kearah yang lebih positif dan produktif.

Dalam hal ini peran guru Pembimbing sangat membantu dalam pertumbuhan dan perkembangan siswa sebagai peserta didik di sekolah. Bimbingan merupakan bantuan yang diberikan kepada siswa dalam rangka upaya menemukan pribadi yang dimaksudkan agar peserta didik mengenal kekuatan dan kelemahan dirinya sendiri serta menerima secara positif dan dinamis sebagai modal pengembangan diri lebih lanjut.

Menurut Undang-Undang Sistem Pendidikan Nasional Nomor 20 Tahun 2003, pendidikan dilaksanakan dalam bentuk bimbingan, pengajaran, dan latihan. Bimbingan atau membimbing memiliki dua makna yaitu bimbingan secara umum yang mempunyai arti sama dengan mendidik atau menanamkan nilai-nilai, membina moral, mengarahkan siswa supaya menjadi orang baik. Sedangkan makna bimbingan yang secara khusus yaitu sebagai suatu upaya atau program membantu mengoptimalkan perkembangan siswa. Bimbingan ini diberikan melalui bantuan pemecahan masalah yang dihadapi, serta dorongan bagi pengembangan potensi-potensi yang dimiliki siswa (Nana Syaodih Sukmadinata, 2005).

Menurut Syamsu Yusuf dan Juntika Nurihsan (2005) Bimbingan dapat diartikan sebagai upaya pemberian bantuan kepada peserta didik dalam rangka mencapai perkembangannya yang lebih optimal. Selanjutnya menurut Syamsu Yusuf (2005) bimbingan diartikan sebagai suatu proses pemberian bantuan kepada individu yang dilakukan secara berkesinambungan supaya individu tersebut dapat memahami dirinya sendiri, sehingga dia sanggup mengarahkan dirinya dan dapat bertindak secara wajar sesuai dengan tuntutan dan keadaan lingkungan sekolah, keluarga, masyarakat dan kehidupan pada umumnya. Dengan demikian, dia akan dapat menikmati kebahagiaan hidupnya dan dapat memberikan sumbangan yang berarti kepada kehidupan masyarakat pada umumnya.

Bimbingan dapat membantu individu mencapai perkembangan diri secara optimal sebagai makhluk sosial. Menurut Moh. Surya dalam bukunya Dewa Ketut Sukardi (2002) Bimbingan adalah suatu proses pemberian 
bantuan yang terus-menerus dan sistematis dari pembimbing kepada yang dibimbing agar tercapai kemandirian dalam pemahaman diri dan perwujudan diri dalam mencapai tingkat perkembangan yang optimal dan menyesuaikan diri dengan lingkungannya.

Percaya diri adalah pandangan seseorang, gambaran pemikiran dan perasaan yakin, kesanggupan dan keberanian seseorang terhadap segala aspek kemampuan yang dimilikinya. Kepercayaan diri adalah sebagai suatu prinsip yang terpisah lebih bersifat suatu nuansa yang keluar dari pengalaman. Jadikan pengalaman sebagai guru yang terbaik dan jadikan kegagalankegagalan sebagai proses belajar untuk pembentukkan kepercayaan diri. Rasa percaya diri sangat berhubungan dengan rasa keberanian. Dua hal itu terkait dengan tingkat yang elemental dan masing-masing merupakan komponen esensial dari kepemimpinan yang kuat (dalam konteks ini kemampuan memimpin diri sendiri). Rasa percaya diri akan menopang kita untuk mengatasi keraguan diri sendiri.

Sumber dari percaya diri adalah wawasan dan pengetahuan seseorang. Luasnya wawasan dapat memudahkan untuk menyesuaikan diri terhadap dalam segala kondisi. Untuk itu, giat dalam mengeksplorasi kemampuan sangat penting. Mengeksplorasi segenap kemampuan dengan giat belajar dan terus berlatih. Berani mencoba hal-hal baru dan tantangantantangan baru dalam tugas yang dipercayakan. Komunikasi dan interaksi terhadap orang lain juga sangat penting dalam meningkatkan ilmu pengetahuan guna meningkatkan kepercayaan diri. Aktif berinteraksi seperti banyak berbicara dan berdiskusi mengenai pelajaran, masalah-masalah, atau kejadian-kejadian.

\section{Kepercayaan Diri Dalam Bergaul}

Kepercayaan diri dalam bergaul berarti yakin akan kemampuannya untuk menyelesaikan suatu pekerjaan dan masalah. Dengan percaya diri, seseorang merasa dirinya berharga dan mempunyai kemampuan menjalani kehidupan, sehingga dalam pergaulannya baik itu disekolah maupun di rumah, siswa dapat bergaul dengan rasa optimisme dengan mempertimbangkan berbagai pilihan dan membuat keputusan sendiri. Ciriciri perilaku yang mencerminkan percaya diri dalam adalah :

a. Yakin kepada diri sendiri

b. Tidak bergantung kepada orang lain 
c. Tidak ragu-ragu

d. Merasa diri berharga

e. Tidak menyombongkan diri

f. Memiliki keberanian untuk bertindak (Anita Lie :2003 : 4)

Orang yang memiliki percaya diri dapat menyelesaikan tugas atau pekerjaan yang sesuai dengan tahapan perkembangannya dengan baik atau setidaknya memiliki kemampuan untuk belajar cara-cara menyelesaikan tugas tersebut. Orang yang percaya diri mempunyai keberanian dan kemampuan untuk meningkatkan prestasinya sendiri. Selanjutnya orang yang percaya diri juga akan dipercayai oleh orang lain.

\section{Faktor-Faktor yang Mempengaruhi Kepercayaan Diri Dalam Bergaul}

Kepercayaan diri dalam bergaul adalah sesuatu yang sangat penting dalam meraih sukses. Pekerjaan apapun yang dimulai tanpa kepercayaan pada diri sendiri, tidak akan menghasilkan sesuatu yang besar. Memiliki kepribadian pemberani dan percaya diri dalam melakukan segala hal adalah keinginan setiap orang. Usaha dengan cara-cara yang mereka ketahui untuk menghilangkan sifat penakut, pengecut, ragu-ragu, pemalu dan minder telah mereka lakukan. Namun sebagian besar usaha tersebut gagal karena keinginan itu tidak bisa menjangkau alam bawah sadar diri mereka. Faktorfaktor yang mempengaruhi rasa percaya diri pada seseorang menurut Hakim (2002:121) muncul pada dirinya sebagai berikut:

\section{a. Lingkungan keluarga}

Keadaan keluarga merupakan lingkungan hidup yang pertama dan utama dalam kehidupan setiap manusia, lingkungan sangat mempengaruhi pembentukan awal rasa percaya diri pada seseorang. Rasa percaya diri merupakan suatu keyakinan seseorang terhadap segala aspek kelebihan yang ada pada dirinya dan diwujudkan dalam tingkah laku sehari-hari.

Berdasarkan pengertian di atas, rasa percaya diri baru bisa tumbuh dan berkembang baik sejak kecil, jika seseorang berada di dalam lingkungan keluarga yang baik, namun sebaliknya jika lingkungan tidak memadai menjadikan individu tersebut untuk percaya diri maka individu tersebut akan kehilangan proses pembelajaran untuk percaya pada dirinya sendiri. Pendidikan keluarga merupakan pendidikan pertama dan utama yang sangat menentukan baik buruknya kepribadian seseorang. 
b. Pendidikan formal

Sekolah bisa dikatan sebagai lingkungan kedua bagi anak, dimana sekolah merupakan lingkungan yang paling berperan bagi anak setelah lingkungan keluarga di rumah. Sekolah memberikan ruang pada anak untuk mengekpresikan rasa percaya dirinya terhadap teman-teman sebayanya.

Hakim (2002:122) menjelaskan bahwa rasa percaya diri siswa di sekolah bisa dibangun melalui berbagai macam bentuk kegiatan sebagai berikut :

1) Memupuk keberanian untuk bertanya

2) Peran guru/pendidik yang aktif bertanya pada siswa

3) Melatih berdiskusi dan berdebat

4) Mengerjakan soal di depan kelas

5) Bersaing dalam mencapai prestasi belajar

6) Aktif dalam kegiatan pertandingan olah raga

7) Belajar berpidato

8) Mengikuti kegiatan ekstrakulikuler

9) Penerapan disiplin yang konsisten

10) Memperluas pergaulan yang sehat dan lain-lain

\section{c. Pendidikan non formal}

Salah satu modal utama untuk bisa menjadi seseorang dengan kepribadian yang penuh rasa percaya diri adalah memiliki kelebihan tertentu yang berarti bagi diri sendiri dan orang lain. Rasa percaya diri akan menjadi lebih mantap jika seseorang memiliki suatu kelebihan yang membuat orang lain merasa kagum. Kemampuan atau keterampilan dalam bidang tertnetu bisa didapatkan melalui pendidikan non formal misalnya : mengikuti kursus bahasa asing, jurnalistik, bermain alat musik, seni vokal, keterampilan memasuki dunia kerja (BLK), pendidikan keagamaan dan lain sebagainya. Sebagai penunjang timbulanya rasa percaya diri pada diri individu yang bersangkutan.

Faktor-faktor yang mempengaruhi rasa percaya diri yang lain menurut Angelis (2003:4) adalah sebagai berikut: 
1) Kemampuan pribadi: Rasa percaya diri hanya timbul pada saat seseorang mengerjakan sesuatu yang memang mampu dilakukan.

2) Keberhasilan seseorang: Keberhasilan seseorang ketika mendapatkan apa yang selama ini diharapkan dan cita-citakan akan menperkuat timbulnya rasa percaya diri.

3) Keinginan: Ketika seseorang menghendaki sesuatu maka orang tersebut akan belajar dari kesalahan yang telah diperbuat untuk mendapatkannya.

4) Tekat yang kuat: Rasa percaya diri yang datang ketika seseorang memiliki tekat yang kuat untuk mencapai tujuan yang diinginkan.

Dari kedua pendapat di atas, faktor yang sangat mempengaruhi timbulnya rasa percaya diri adalah dukungan orang tua terhadap anak dalam bergaul dan perkembangannya yang bertanggung jawab akan dapat mmberikan dampak yang baik dalam proses terbentuknya rasa percaya diri kepada anak. Selain itu kehadiran guru pembimbing sangat berpengaruh sekali dalam membantu meningkatkan rasa percaya diri pada siswa. Mereka merasa selalu di ayomi sehingga menghasilkan positif pada diri anak dalam bergaul.

Berdasarkan uraian di atas dapat disimpulkan bahwa faktorfaktor yang mempengaruhi rasa percaya diri adalah faktor internal dan eksternal. Faktor internal yaitu kemampuan yang dimiliki individu dalam mengerjakan sesuatu yang mampu dilakukannya, keberhasilan individu untuk mendapatkan sesuatu yang mampu dilakukan dan dicita-citakan, keinginan dan tekat yang kuat untuk memperoleh sesuatu yang diinginkan hingga terwujud. Faktor eksternal yaitu lingkungan keluarga di mana lingkungan keluarga akan memberikan pembentukan awal terhadap pola kepribadian seseorang. Yang kadua adalah lingkungan formal atau sekolah, dimana sekolah adalah tempat kedua untuk senantiasa mempraktikkan rasa percaya diri individu atau siswa yang telah didapat dari lingkungan keluarga kepada teman-temannya dan kelompok bermainnya. Yang ketiga adalah lingkungan pendidikan non formal temapat individu menimba ilmu secara tidak langsung belajar ketrampilan-keterampilan sehingga tercapailah keterampilan sebagai salah satu faktor pendukung guna mencapai rasa percaya diri pada individu yang bersangkutan. 


\section{d. Cara Membantu Meningkatkan Percaya Diri Dalam Bergaul}

Masalah percaya diri adalah masalah yang sangat krusial dan penting dalam kepribadian sebagai manusia. Saya banyak melihat, bahwa sebenarnya masalah kurang percaya diri ini banyak dipengaruhi oleh kurangnya pengetahuan kita tentang bagaimana membangunnya.

Adapun cara yang dapat dilakukan oleh seorang guru pembimbing dalam membantu meningkatkan percaya diri adalah memberikan pemahaman tentang :

a. Potensi diri

Potensi diri pada masing-masing anak bisa berbeda-beda. Ada yang bisa digali dari hasil akademisnya atau prestasi di sekolahnya. Namun, bukan berarti anak yang tidak berprestasi di sekolah tak memiliki sumber percaya diri tersebut. Potensi diri anak bisa digali dari jalur lainnya, misalnya kemampuan menyanyi, menari, atau juga sifat baik hati, ringan tangan, dan sebagainya.

Hal yang hampir sama dikemukakan International Director John Robert Power untuk Indonesia, Indayati Oetomo. Menurutnya, seorang anak yang percaya diri tidak selalu berarti pandai, namun ia berani tampil dan mampu bersosialisasi dengan baik. "Anak itu juga biasanya atraktif," katanya di sela-sela acara pencarian anakanak percaya diri “

b. Menanamkan sikap percaya diri dalam bergaul

Menanamkan sikap percaya diri hendaknya dilakukan sedini mungkin,.karena sifatnya bukan instan, sebaiknya rasa percaya diri dipupuk sejak kecil. Jika sejak kecil anak sudah memiliki rasa percaya diri yang kuat, lebih mudah untuk mengembangkan diri dan potensi yang ada pada dirinya.

Percaya diri adalah bahan bakar utama keberhasilan seseorang dalam hidup ini. Begitu bahan bakar itu didapat, tercapainya keberhasilan dalam segala kegiatan hanya masalah waktu, tergantung usaha yang dilakukan seseorang.

Saat orang tua ingin anaknya percaya diri, sebaiknya ia tidak overprotective Lepaskan anak untuk berkiprah dan orang tua mendorong dari belakang. Jangan terlalu banyak larangan, sehingga anak nanti ketakutan sendiri. Jangan menargetkan sesuatu untuk 
anak. Obsesi orang tua justru akan menekan anak. Berikan anak kenyamanan, bukan tekanan. Akan tetapi Intervensi yang terlalu banyak dari orang tua, akan mematikan kreativitas anak. Makanya, ia menyarankan, orang tua melatih anak sedini mungkin untuk ikut berkompetisi, berani tampil, sehingga ia kelak menjadi percaya diri. Sumber : pikiran-rakyat.com

c. Memberi pemahaman diri dalam bergaul

Pemahaman tentang diri yang baik dimaksudkan dalam pengembangan diri ini adalah usaha untuk mampu mengatur kegiatan, memilih kegiatan yang sesuai dengan kemampuan yang dimiliki, menemukan cara dalam bergaul yang tepat dan mampu mengatasi kesulitan yang timbul akibat dari tuntutan pelajaran yang diterimanya.

Menurut Ketut Sukardi (2000:46) bahwa pengembangan pemahaman tentang diri yang perlu mendapatkan perhatian guru pembimbing meliputi : pemahaman sikap, sifat, kebiasaan, bakat minat, kekuatan-kekuatan dan penyalurannya, kelemahankelemahan dan penanggulangannya dan usaha-usaha-usaha pencapaian cita-cita atau perencanaan masa depan.

d. Mengenal diri sendiri secara utuh

Segala hal tentang apa yang disukai berkenaan dengan diri sendiri dan segala yang diketahui dapat dilakukan dengan baik. Jika kesulitan melakukan ini, ingat tentang pujian yang telah diperoleh dari orang-orang Apa yang mereka katakan dan dicontoh dengan melakukannya dengan baik. Sebuah gagasan bagus untuk menuliskan semua ini, hingga bisa melihatnya lagi untuk mengibarkan rasa percaya diri kapanpun Anda membutuhkan inspirasi

e. Sering latihan

Kapanpun seseorang ingin merasakan rasa percaya diri, kuncinya adalah latihan sesering mungkin. Bahkan pelatihan itu dapat membawanya dalam tidur. Dengan kemampuan yang terlatih, tak akan kesulitan menampilkan rasa percaya diri kapanpun itu dibutuhkan

f. Bergaul dengan orang-orang yang memiliki rasa percaya diri dan berpikiran positif 
Lingkungan membawa pengaruh besar pada seseorang. Jika seseorang terus menerus berbaur dengan orang yang memiliki rasa rendah diri, pengeluh dan pesimis, seberapa besarpun percaya diri yang dimiliki, perlahan tapi pasti akan pudar dan terseret mengikuti lingkungan. Sebaliknya, jika selalu dikelilingi orang-orang yang penuh kebahagiaan dan percaya diri, makan akan tercipta pula atmosfir positif yang membawa keuntungan bagi diri.

\section{e. Penutup}

Kepercayaan diri dalam bergaul adalah sesuatu yang sangat penting dalam meraih sukses. Pekerjaan apapun yang dimulai tanpa kepercayaan pada diri sendiri, tidak akan menghasilkan sesuatu yang besar. Memiliki kepribadian pemberani dan percaya diri dalam melakukan segala hal adalah keinginan setiap orang. Usaha dengan cara-cara yang mereka ketahui untuk menghilangkan sifat penakut, pengecut, ragu-ragu, pemalu dan minder telah mereka lakukan. Namun sebagian besar usaha tersebut gagal karena keinginan itu tidak bisa menjangkau alam bawah sadar diri mereka. Orang yang memiliki percaya diri dapat menyelesaikan tugas atau pekerjaan yang sesuai dengan tahapan perkembangannya dengan baik atau setidaknya memiliki kemampuan untuk belajar cara-cara menyelesaikan tugas tersebut. Orang yang percaya diri mempunyai keberanian dan kemampuan untuk meningkatkan prestasinya sendiri. Selanjutnya orang yang percaya diri juga akan dipercayai oleh orang lain.

Kepercayaan diri dalam bergaul berarti yakin akan kemampuannya untuk menyelesaikan suatu pekerjaan dan masalah. Dengan percaya diri, seseorang merasa dirinya berharga dan mempunyai kemampuan menjalani kehidupan, sehingga dalam pergaulannya baik itu disekolah maupun di rumah, siswa dapat bergaul dengan rasa optimisme dengan mempertimbangkan berbagai pilihan dan membuat keputusan sendiri.

\section{Daftar Pustaka}

Anita Lei. (2004) . 101 Cara Menumbuhkan Percaya Diri Anak, Jakarta, Elex Media Kompotindo 
Ahmadi Abu, (1991), Psikologi Perkembangan, Jakarta, Rineka Cipta, Ahyadi, Abdul Azis, (1993) Psikologi Agama Kepribadian Muslim Pancasila, Sinar Baru.

Andi Mappiare, (1984), Pengantar Bimbingan dan Penyuluhan di Sekolah, Surabaya : Usaha Nasional

Christiana Weni (2010) 101 Mencari Teman Dan Mempengaruhi Orang Lain. Jakarta. Media Pressindo

D.Gunarsa. (2002). Psikologi Untuk Membimbing. Jakarta : Gunung Mulia

Dewa Ketut Sukardi, (1995), Dasar-Dasar Bimbingan dan Penyuluhan di Sekolah, Surabaya : Usaha Nasional

DEPDIKNAS, (2007) Rambu-Rambu Penyelenggaraan Bimbingan Dan Konseling Dalam Jalur Pendidikan Formal

Gunarso, Singgih, Yulia Singgih, 1991. Psikologi Perkembangan Anak dan Remaja, Jakarta Gunung Mulia

Hadari Nawawi. (1999) Menjadi Guru Profesional. Jakarta: Bumi Aksara

Hibana S. Rahman, (2003), Bimbingan dan Konseling Pola 17, Yogyakarta : NCY Press

Jalalludin. (1988). Psikologi Perkembangan, Jakarta, Grafindo Persada

Prayitno dan Erman Amti, (2004) Dasar-Dasar Bimbingan Dan Konseling, Jakarta : Renika Cipta

Rochamn Natawijaya, (1985), Bimbingan Penyuluhan di SPG, Jakarta : Depdikbud

Roestiyah NK. (1982) Masalah-Masalah Ilmu Keguruan, Bandung: Bina Aksara

Sofyan S. Willis, (2004) Konseling Individual Teori Dan Praktek,. Bandung : Alfabeta

Suwarno. (1981). Pengantar Ilmu Pendidikan. Jakarta: Aksara Baru

Sudarsono. (1990) Kenakalan Remaja.. Jakarta : Rineka Cipta

Tafsir, Ahmad, (1994) Ilmu Pendidikan Dalam Perspektif Islam, Bandung, Remaja Rosdakarya

Tohirin, (2007), Bimbingan dan Konseling di Sekolah dan maDrasah (Berbasis Integrasi), Jakarta : PT Raja Grafindo Persada

Usman, Uzer, (1990) Menjadi Guru Profesional, Remaja Rosdakarya,.

Will Glennon. (2007). Cara Meningkatkan Rasa Percaya Diri Pada Anak Perempuan. Jakarta. Arcan 
Winkel, W.S (1985). Bimbingan dan Konseling Disekolah Menengah. Jakarta : Gramedia

Yuline dkk. (2008) Pelayanan Bimbingan dan Konseling di Sekolah. Pontianak : Universitas Tanjungpura

Zakiyah Darajat. (1995) Remaja Harapan Dan Tantangan. Jakarta : Ruhama 